\section{p-ISSN 2476-9886 \\ e-ISSN 2477-0302 \\ J.Edu}

Volume 4 Nomor 1, April 2018, HIm 7-15

\section{Jurnal EDUCATIO}

Jurnal Pendidikan Indonesia

DOI: https://doi.org/10.29210/120182132

Akses Online :

http://jurnal.iicet.org

Dipublikasikan oleh :

Indonesian Institute for Counseling, Education and Therapy (IICET)

Info Artikel:

Diterima: 10/03/2018

Direvisi: 20/03/2018

Dipublikasikan: 15/04/2018

\title{
PENINGKATAN KEMAMPUAN BERBICARA MELALUI MEDIA GAMBAR SERI DI KELAS III SDN. 14 SIGUNTUR MUDA KECAMATAN KOTO XI TARUSAN KABUPATEN PESISIR SELATAN
}

\author{
Desmiyetri $^{1}$
}

${ }^{1}$ SDN 14 Siguntur Muda

\begin{abstract}
This research is motivated by the lack of ability of students in speaking because at the time of the learning process teachers still use the lecture method. The results showed increased student activity and teacher activity. So, it can be concluded that learning ability to speak through the media drawing series in class III SDN. 14 Young Siguntur, can improve students' speaking ability.
\end{abstract}

Keyword: media image's series, classroom action research

\section{PENDAHULUAN}

Pembelajaran Berbahasa Indonesia mencakup empat aspek kemampuan berbahasa yaitu kemampuan menyimak, kemampuan berbicara, kemampuan membaca dan kemampuan menulis. Satu kemampuan berbahasa saling terkait dengan kemampuan berbahasa lainnya, salah satunya keterampilan berbicara.

Menurut Tarigan (2007:15) "kemampuan berbicara diartikan kemampuan mengucapkan bunyi-bunyi bahasa untuk mengekspresikan atau menyampaikan pikiran, gagasan atau perasaan secara lisan". kemampuan berbicara merupakan salah satu bentuk kemampuan berbahasa yang sangat penting bagi siswa, di samping kemampuan berbahasa menyimak, menulis dan membaca.

Dalam ketepatan berbicara siswa harus mampu mengutarakan gagasan, menjawab pertanyaan dengan baik dan mengajukan pertanyaan dengan baik sehingga siswa mengerti apa maksud pertanyaan. Ketika melaksanakan pembelajaran diskusi, siswa dituntut terampil mengemukakan pendapat, mempertahankan pendapat siswa lain atau mempengaruhi siswa lain agar mengikuti alur pemikirannya.

Dalam proses pembelajaran penggunaan media gambar mempunyai arti yang cukup penting. Media merupakan alat untuk membantu siswa memahami pembelajaran dengan mudah. Kerumitan materi pembelajaran 
yang akan disampaikan kepada siswa dapat disederhanakan dengan bantuan media dan materi pembelajaran yang abstrak dapat disajikan melalui media.

Untuk mencapai sasaran dan target dari pembelajaran tersebut, guru seharusnya mampu melaksanakan alat, bahan, dan media, agar mudah digunakan oleh siswa, salah satu media yang sesuai dengan materi pembelajaran berbahasa Indonesia SD adalah media gambar seri. Media ini termasuk salah satu jenis visual yang bermanfaat untuk mengkongkritkan hal-hal yang bersifat abstrak, gambar atau foto juga dapat menggambarkan, mengekpresikan pikiran dan gagasan secara lisan.

Mengingat pentingnya media pembelajaran, seorang guru dituntut agar mampu menggunakan media gambar seri dalam proses pembelajaran, sehingga hal tersebut dapat meningkatkan motivasi belajar (Fitri, E., Ifdil, I., \& Neviyarni, S., 2016) dan merangsang keaktifan siswa dalam proses kemampuan berbicara dalam pembelajaran pendidikan Bahasa Indonesia di Sekolah Dasar (SD).

Berdasarkan hasil observasi awal di kelas III SDN 14 Siguntur Muda, ternyata pembelajaran kemampuan berbicara yang selama ini dilakukan hanya sebatas tanya jawab dengan siswa dan guru hanya meminta beberapa orang siswa untuk bercerita didepan kelas dengan melihat gambar di buku paket, karena guru kelas III ini tidak menggunakan media gambar seri yang memadai di depan kelas, akibatnya tidak semua siswa untuk berani tampil berbicara di depan kelas. Selain itu pencapaian hasil bahasa Indonesia kelas III SDN 14 Siguntur Muda Kecamatan Koto XI Tarusan. Pada semester ganjil 2015/2017 hanya mencapai 42,85\% yang tuntas dan 57,15\% tidak tuntas dengan KKM 60 (tabel 1).

Tabel 1. Hasil Belajar Siswa Kelas III Semester I

\begin{tabular}{cccc}
\hline Kelas & KKM & \multicolumn{2}{c}{ Ketuntasan } \\
\cline { 3 - 4 } & & \% tuntas & \% tidak tuntas \\
\hline III & 60 & 42,85 & 57,15 \\
\hline
\end{tabular}

Dari fenomena yang diperoleh di lapangan, maka peneliti menganggap hal ini perlu dikaji, dan perlu dikembangkan suatu pembelajaran yang bermakna, sehingga tercipta suasana pembelajaran yang kondusif saling termotivasi untuk berbicara secara berurutan.

\section{METODOLOGI}

Penelitian ini dilaksanakan di SDN. 14 Siguntur Muda Kecamatan Koto XI Tarusan Kabupaten Pesisir Selatan tahun 2017, dengan pertimbangan siswa kelas III di SDN. 14 Siguntur Muda Kecamatan Koto XI Tarusan Kabupaten Pesisir Selatan belum maksimal dalam pembelajaran kemampuan berbicara.

Penelitian ini menggunakan pendekatan kualitatif. Menurut Sugiyono, (2007:309) mengemukakan dalam penelitian kualitatif, pengumpulaan data di lakukan pada natural setting (kondisi yang alamiah), sumber data primer, dan teknik pengumpulan data lebih banyak pada observasi berperan serta (participan observation), wawancara mendalam (in depth intriview) dan dokumentasi.Selanjutnya Nasution (dalam Sugiyono, 2007:306) menyampaikan bahwa dalam penelitian kualitatif, tidak ada pilihan lain dari pada menjadikan manusia sebagai instrumen penelitian utama.

Penelitian kualitatif mementingkan proses dari pada hasil, metode penelitian kualitatif ini juga dilakukan secara intensive, peneliti ikut berpartisifasi aktif di lapangan, mencatat secara kata-kata apa yang terjadi, melakukan analisis relektif terhadap berbagai dokumen yang ditemukan dilapangan dan membuat laporan penelitian secara mendetail.

Jenis penelitian yang digunakan dalam pelaksanaan penelitian dilapangan adalah penelitian tindakan kelas (PTK). PTK adalah sebuah penelitian yang dilakukan oleh guru di dalam kelasnya sendiri, dengan tujuan untuk memperbaiki kinerjanya sebagai seorang guru sehingga hasil belajar siswa meningkat (Wardhani: 2004). 
Teknik pengumpulan data yang digunakan adalah observasi, diskusi dan tes. Analisis data menggunakan analisis data kualitatif seperti yang ditawarkan oleh Miles dan Huberman (dalam Mustika, 2012:40) yaitu: analisis data dimulai dengan menelaah sejak pengumpulan data sampai seluruh data terkumpul. Data tersebut direduksi berdasarkan masalah yang diteliti, diikuti penyajian data, dan terakhir menyimpulkan atau verifikasi". Tahap analisis yang demikian dilakukan berulang-ulang begitu data selesai dikumpulkan pada setiap tahap pengumpulan data dalam setiap tindakan.

\section{HASIL DAN PEMBAHASAN}

\section{Siklus I}

Pada bagian berikut diuraikan tentang hasil penelitian dan pembahasan penelitian siklus I yang meliputi proses dan hasil pelaksanaan tindakan pembelajaran kemampuan berbicara melalui media gambar seri, yang terdiri atas (a) perencanaan, (b) pelaksanaan tindakan, (c) pengamatan, dan (d) refleksi. Keempat hal tersebut disajikan berikut ini.

\section{1) Perencanaan tindakan}

Penggunaan gambar seri dalam pembelajaran kemampuan berbicara disusun dan diwujudkan dalam bentuk rencana pembelajaran. Rencana pembelajaran ini disusun secara kolaboratif antara penulis dan obsever. Rencana pembelajaran tersebut disusun berdasarkan program semester I. Perencanaan tindakan ini terdiri dari, langkahlangkah, media, dan penilaian.

Standar Kompetensi yang ingin dicapai adalah: "Mengungkapkan pikiran, perasaan, pengalaman dan petunjuk dengan bercerita dan memberikan tanggapan/saran". Kompetensi Dasarnya adalah: "Menjelaskan urutan membuat atau melakukan cara membuat air mancur mainan dengan dengan kalimat yang jelas dan mudah dipahami”. SK dan KD tersebut tercermin dalam indikator pembelajaran. Indikator yang ingin dicapai oleh siswa mampu: (1) mengurutkan gambar seri, (2) menjelaskan urutan membuat air mancur mainan, (3) memperagakan urutan membuat air mancur mainan.

Untuk mencapai indikator tersebut, rencana pembelajaran dibagi menjadi tiga tahap, yaitu: (1) kegiatan awal, (2) kegiatan inti, (3) kegiatan akhir. Ketiga tahap kegiatan ini tidak berdiri sendiri, melainkan terkait antara kegiatan satu dengan kegiatan lainnya.

Langkah-langkah pembelajaran untuk mencapai pembelajaran kemampuan berbicara sebagai berikut: (1) menyiapkan siswa untuk memulai pelajaran, (2) menugasi siswa mengamati gambar seri yang dipajang, (3) menugasi siswa mengurutkan gambar seri yang sesuai dengan urutan membuat air mancur mainan, (4) meminta siswa untuk mencatat urutan membuat air mancur mainan sesuai dengan urutan gambar seri yang diberikan, (5) meminta siswa menyampaikan urutan membuat air mancur mainan, (6) menyuruh siswa memperagakan urutan membuat atau ir mancur mainan sesuai dengan gambar seri yang diberikan, (7) menyuruh siswa menceritakan urutan membuat air mancur mainan dengan menggunakan bahasa sendiri.

Penilaian pembelajaran yang direncanakan adalah penilaian proses dan hasil. Aspek yang dinilai pada proses yaitu menceritakan kembali urutan membuat air mancur mainan yang ada pada gambar seri, memperagakan ke depan kelas urutan membuat air mancur mainan sambil menceritakannya. Untuk penilaian hasil pembelajaran berbicara siswa yakni: (1) kemampuan menyampaikan urutan gambar seri, (2) menjelaskan urutan air mancur mainan, (3) menceritakan cara membuat air mancur mainan.

\section{2) Pelaksanaan}

Pelaksanaan proses pembelajaran kemampuan berbicara melalui media gambar seri di kelas III SDN. 14 Siguntur Muda Kecamatan Koto XI Tarusan Kabupaten Pesisir Selatan. Penelitian siklus I dilaksanakan dua kali pertemuan yaitu hari Selasa tanggal 6 September 2017, kemudian hari Kamis tanggal 8 September 2017. Pada pertemuan pertama kegiatan yang dilakukan adalah mengurutkan gambar seri yang sesuai dengan gambar seri yang diberikan. Sedangkan memperagakan urutan membuat atau melakukan sesuatu yang sesuai dengan gambar seri dengan menggunakan bahasa sendiri dilaksanakan pada pertemuan kedua yaitu hari Kamis tanggal 8 September 2017. 
Tindakan 1 (pertemuan I)

Pertemuan ini dilaksanakan dalam waktu 2x35 menit pada hari Selasa 6 September 2017. Materi pelajaran tentang air mancur mainan. Sedangkan media yang digunakan adalah gambar seri yang bertema tentang cara membuat air mancur.

Selanjutnya guru mengajak siswa memperhatikan gambar seri yang dipajang di depan kelas. Kemudian guru memotivasi siswa mengurutkan gambar seri yang dipajang. Selanjutnya guru menyuruh siswa mencatat urutan cara membuat air mancur mainan sesuai urutan gambar seri yang diberikan. Setelah itu guru meminta siswa menyampaikan cara membuat air mancur mainan sesuai dengan gambar seri yang diberikan kegiatan terlihat dalam dialog.

Dari gambaran proses pembelajaran yang telah berlangsung tersebut dapat disimpulkan bahwa siswa belum cukup mempunyai keberanian dan masih malu-malu dalam mengemukakan pendapat dan idenya dalam menjawab pertanyaan-pertanyaan yang diberikan oleh guru. Kondisi ini terbukti dengan banyaknya anak yang belum mau mengangkat tangan ketika disuruh mengurutkan gambar seri yang diberikan guru. Dan sedikit siswa yang mau mengangkat tangan untuk menyampaikan urutan dari gambar seri yang di pajang.

Tindakan II (pertemuan II)

Pertemuan II ini dilaksanakan dalam waktu 2x35 menit. Pada hari Kamis 8 September 2017 pada jam pelajaran ketiga dan empat. Pertemuan ini adalah lanjutan dari pertemuan 1 siklus I.

Kegiatan awal dimulai dengan menyapa siswa dan mengucapkan salam. Kemudian guru bersama siswa memperhatikan gambar seri yang dipajang di depan kelas. Setelah situasi siswa siap untuk memulai pelajaran, kegiatan pembelajaran dilanjutkan dengan menjelaskan tujuan dan langkah-langkah pembelajaran yang akan dilaksanakan. Kegiatan berikutnya adalah memperagakan membuat air mancur mainan sesuai dengan urutan media gambar seri yang dipajang, dan menyuruh siswa untuk memperagakan sesuai dengan gambar yang telah di urutkan dengan baik.

Pada tahap ini yang dilakukan oleh peneliti yaitu guru kelas III SDN. 14 Siguntur Muda Kecamatan Koto XI Tarusan Kabupaten Pesisir Selatan sebagai pengamat I dan observer sebagai pengamat II. Guru kelas sebagai pengamat I mengamati kegiatan yang dilakukan siswa, sedangkan pengamat II mengamati dari aspek kegiatan guru. Hal ini dilaksanakan untuk mendapatkan informasi dari guru, siswa, dan pengamat terhadap pelaksanaan proses pembelajaran yang berlangsung pada siklus I.

Hasil observasi proses kegiatan guru

Tabel 2. Persentase Observasi Aktivitas Guru dalam Pelaksanaan Pembelajaran Siklus I

\begin{tabular}{lcc}
\hline & Pertemuan & Pesentase \\
\hline & 1 & $58 \%$ \\
Rata-rata $(\%)$ & 2 & $\mathbf{7 5 \%}$ \\
\hline
\end{tabular}

Secara umum keberhasilan tindakan yang dilakukan guru dalam proses pelaksanaan pembelajaran telah mencapai $66,5 \%$. Berikut adalah tabel yang menunjukkan hasil observasi proses kegiatan guru dalam siklus I.

Hasil observasi proses kegiatan siswa

Tabel 3. Persentase Observasi Aktivitas Siswa dalam Pelaksanaan Pembelajaran Pada Siklus I

\begin{tabular}{cc}
\hline Pertemuan & Pesentase \\
\hline 1 & $\mathbf{5 0 \%}$ \\
2 & $\mathbf{6 6 \%}$ \\
Rata-rata $(\%)$ & $\mathbf{5 8 \%}$ \\
\hline
\end{tabular}


Dari tabel di atas dapat diperoleh gambaran persentase kegiatan siswa dalam proses pelaksanaan pembelajaran kemampuan berbicara melalui media gambar seri pada akhir siklus I.

\section{Analisis hasil belajar siswa \\ Tabel 4. Rata-rata dan Persentase Hasil Belajar Siswa pada Siklus I.}

\begin{tabular}{cc}
\hline Jumlah siswa yang mengikuti tes & 14 orang \\
\hline Rata-rata nilai hasil belajar & 50,57 \\
Persentase ketuntasan kelas & $\mathbf{3 5 , 7 1 \%}$ \\
\hline
\end{tabular}

\section{3) Refleksi}

Refleksi dilaksanakan secara kolaboratif antara penulis dengan guru kelas dan teman sejawat yang telah mengadakan pengamatan selama proses pembelajaran berlangsung. Dari kegiatan pembelajaran yang berlangsung selama dua kali pertemuan, penulis menyadari masih ada kendala yang dihadapi di antaranya:

\section{Kegiatan Awal}

Ketika guru menyiapkan kondisi kelas masih banyak siswa yang ribut, jadi pada saat guru menyampaikan tujuan pembelajaran jadinya kurang efektif dan guru memotivasi siswa untuk giat dalam proses pembelajaran agar siswa mampu untuk mengerjakan tugas yang diberikan guru.

\section{Kegiatan Inti}

Ketika guru menyuruh siswa mengamati gambar seri yang dipajang di depan kelas, masih ada siswa yang masih ngobrol dan tidak memperhatikan apa yang disuruh oleh guru, guru menyuruh siswa mengurutkan gambar seri yang diberikan, lalu guru meminta siswa untuk menceritakan urutan cara membuat air mancur mainan sesuai dengan urutan gambar seri yang diberikan ke depan kelas.

Kegiatan Akhir

Pada saat menyimpulkan pembelajaran siswa banyak yang tidak ingat lagi pelajaran yang baru dijelaskan karena mereka pada saat guru menjelaskan pelajaran banyak siswa yang tidak memperhatikan, lalu guru memberikan tes kepada siswa, memberikan penghargaan atas keberhasilan siswa dalam pembelajaran, dan memberikan PR. Setelah diadakan refleksi dengan para pengamat, untuk perbaikan siklus berikutnya maka diadakan perbaikan di antaranya: (1) Membimbing siswa untuk selalu siap untuk menerima pelajaran yang diberikan guru (2) Membimbing siswa untuk mendengarkan apa yang dijelaskan guru sehingga pelajaran yang diberikan oleh guru dapat diterima secara baik (3) Membimbing siswa untuk mau menjelaskan cara membuat air mancur mainan ke depan kelas karena kita harus berani belajar berbicara di depan umum, dimulai dari kelas kita terlebih dahulu sampai seterusnya (4) Memberi motivasi kepada siswa untuk memperagakan bagimana cara membuat air mancur mainan, karena apabila memperagakan cara membuat air mancur mainan yang bagus guru akan memberikan penghargaan. Guru hendaknya bisa membujuk siswa yang malu-malu untuk memperagakan cara membuat air mancur mainan di depan kelas.

Perhatian guru tidak hanya terfokus pada gambar tetapi lebih bisa meningkatkan pengelolaan kelas dan melibatkan seluruh siswa dalam proses pembelajaran.

\section{Siklus II}

Pada bagian berikut diuraikan tentang hasil penelitian dan pembahasan penelitian siklus II yang meliputi proses dan hasil pelaksanaan tindakan pembelajaran kemampuan berbicara melalui media gambar seri, yang terdiri atas (a) perencanaan, (b) pelaksanaan tindakan, (c) pengamatan, dan (d) refleksi. Keempat hal tersebut disajikan berikut ini:

\section{1) Perencanaan Tindakan}

Penggunaan gambar seri dalam pembelajaran kemampuan berbicara diwujudkan dalam bentuk rencana pelaksanaan pembelajaran (RPP). Perencanaan pada siklus II pada garis besarnya sama dengan perencanaan pembelajaran pada siklus I. Perbedaan hanya dilihat dari segi media gambar seri yang digunakan. 
Standar Kompetensi yang ingin dicapai adalah: "Mengungkapkan pikiran, perasaan, pengalaman dan petunjuk dengan bercerita dengan memberikan tanggapan/saran". Kompetensi Dasarnya adalah: "menjelaskan urutan membuat atau melakukan sesuatu dengan kalimat yang runtut dan mudah di pahami". SK dan KD tersebut tercermin dalam indikator: (1) mengurutkan cara membuat sesuatu (layang-layang) (2) menjelaskan gambar dengan kalimat sendiri dan tampil ke depan kelas, (3) memperagakan cara membuat layang-layang yang sesuai dengan gambar seri.

Untuk mencapai indikator tersebut, rencana pembelajaran dibagi menjadi tiga tahap, yaitu: (1) kegiatan awal, (2) kegiatan inti, (3) kegiatan akhir. Ketiga tahap kegiatan ini tidak berdiri sendiri, melainkan terkait antara kegiatan satu dengan kegiatan lainnya.

Langkah-langkah pembelajaran untuk mencapai pembelajaran kemampuan berbicara sebagai berikut: (1) menyiapkan siswa untuk memulai pelajaran, (2) menugasi siswa mengamati gambar seri yang dipajang, (3) menugasi siswa mengurutkan gambar seri yang sesuai dengan menjelaskan urutan membuat atau melakukan sesuatu, (4) meminta siswa mengubah membahasakan gambar seri yang menjadi kalimat yang baik dan benar sesuai dengan bahasa sendiri, (5) memberikan latihan kepada siswa untuk melengkapi kalimat cara melakukan sesuatu yang sesuai dengan gambar seri yang ada di depan, (6) meminta siswa memperagakan cara melakukan sesuatu ke depan kelas dengan teman sebangku sesuai dengan gambar seri yang telah dilengkapi.

Penilaian pembelajaran yang direncanakan adalah penilaian proses dan hasil. Aspek yang dinilai pada proses yaitu meminta siswa mengurutkan gambar serta melengkapi kalimat penjelasan urutan melakukan sesuatu yang sesuai dengan gambar seri yang ada didepan dan memperagakan cara melakukan sesuatu kedepan kelas dengan teman sebangku sesuai dengan gambar seri yang telah dilengkapi. Untuk penilaian hasil diarahkan pada kemampuan siswa dalam keterampilan berbicara dengan memperhatikan kriteria penilaian yang telah ditetapkan.

\section{2) Pelaksanaan}

Penelitian siklus II dilaksanakan dua kali pertemuan yaitu hari Selasa tanggal 13 September 2017 pada jam pelajaran pertama dan kedua. Kemudian hari Selasa tanggal 20 September 2017 pada jam pelajaran ketiga dan keempat.

a) Tindakan II (pertemuan I)

Pertemuan ini dilaksanakan dalam waktu 2x35 menit pada hari Selasa tanggal 13 September 2017. Materi pelajaran tentang melakukan tanya jawab dengan teman sebangku. Sedangkan media yang digunakan adalah gambar seri layang- layang.

Tahap ini diawali dengan memajang gambar seri yang telah dipersiapkan guru gunanya untuk membantu siswa dalam mengurutkan gambar dengan teman sebangkunya. Selanjutnya guru mengajak siswa memperhatikan gambar seri yang dipajang di depan kelas. Guru menyuruh siswa mengurutkan gambar dengan teman sebangku sesuai dengan gambar seri yang dipajang. Kemudian guru membimbing siswa menjelaskan cara membuat layanglayang.

b) Tindakan II (pertemuan II)

Pertemuan II ini dilaksanakan dalam waktu 2x35 menit. Pada hari Selasa tanggal 20 September 2017 pada jam pelajaran ketiga dan keempat. Tahap ini diawali dengan memajang gambar seri yang telah dipersiapkan guru gunanya untuk membantu siswa untuk melengkapi kalimat sesuai dengan gambar seri yang dipajang. Selanjutnya guru membimbing siswa melengkapi kalimat dan menyuruh siswa menjelaskan cara melakukan sesuatu sesuai dengan gambar seri yang diberikan oleh guru.

Kemudian guru membimbing siswa dalam melengkapi urutan melakukan sesuatu yang sesuai dengan gambar seri yang dipajang dan menyuruh siswa memperagakan ke depan kelas.

\section{3) Pengamatan}

Pada tahap ini yang dilakukan oleh peneliti yaitu guru kelas III SDN. 14 Siguntur Muda Kecamatan Koto XI Tarusan Kabupaten Pesisir Selatan sebagai pengamat I dan obsever sebagai pengamat II. Guru kelas sebagai 
pengamat I mengamati kegiatan yang dilakukan siswa, sedangkan pengamat II mengamati dari aspek kegiatan guru.

Kegiatan ini dilaksanakan untuk mendapatkan informasi dari siswa, guru, dan pengamat terhadap pelaksanan proses pembelajaran yang berlangsung pada siklus II.

Hasil observasi proses kegiatan guru

Tabel 5. Persentase Observasi Aktivitas Guru dalam Pelaksanaan Pembelajaran Siklus II

\begin{tabular}{cc}
\hline Pertemuan & Persentase \\
\hline 1 & 83 \\
2 & 92 \\
Rata-rata $(\%)$ & 87.5 \\
\hline
\end{tabular}

Secara umum keberhasilan tindakan yang dilakukan guru dalam proses pelaksanaan pembelajaran telah mencapai $84,5 \%$. Berikut adalah tabel yang menunjukkan hasil observasi proses kegiatan guru dalam siklus II.

Hasil observasi proses kegiatan siswa

Tabel 6. Persentase Observasi Aktivitas Siswa dalam Pelaksanaan Pembelajaran Pada Siklus II

\begin{tabular}{cc}
\hline Pertemuan & Persentase \\
\hline 1 & 75 \\
2 & 91 \\
Rata-rata $(\%)$ & 83 \\
\hline
\end{tabular}

Dari tabel di atas dapat diperoleh gambaran persentase kegiatan siswa dalam proses pelaksanaan pembelajaran kemampuan berbicara melalui media gambar seri pada akhir siklus II.

Analisis hasil belajar siswa

Tabel 7. Rata-rata dan Persentase Hasil Belajar Siswa pada Siklus II.

\begin{tabular}{cc}
\hline Jumlah siswa yang mengikuti tes & 14 orang \\
\hline Rata-rata nilai hasil belajar & $\mathbf{8 3 , 9 3}$ \\
Persentase ketuntasan kelas & $\mathbf{9 2 , 8 5 \%}$ \\
\hline
\end{tabular}

Berdasarkan tabel di atas, hasil tes siklus II menunjukkan hasil belajar siswa lebih baik dibandingkan dengan siklus I. Hal ini terlihat pada persentase ketuntasan belajar secara klasikal. Pada siklus I terdapat 35,71\% siswa yang tuntas belajar dengan rata-rata skor tes 50 . Sedangkan pada siklus II terdapat $92,85 \%$ siswa yang tuntas belajar dengan rata-rata skor tes 83,93. Dengan demikian, persentase ketuntasan secara klasikal dan ratarata hasil belajar siswa mengalami peningkatan yang signifikan.

\section{4) Refleksi}

Refleksi dilaksanakan untuk mengetahui apakah tindakan pada siklus II sudah berhasil atau belum. Jika belum maka penelitian dilanjutkan pada siklus berikutnya. Berdasarkan pengamatan, pembelajaran sudah terlaksana dengan baik.

Dilihat dari persentase hasil belajar siswa sudah mencapai tingkat keberhasilan belajar yang baik, sedangkan data pengamatan aktivitas guru dalam mengelola pembelajaran sudah mengalami peningkatan dibandingkan pada siklus I, dan dapat dikatakan sudah baik.

Pada observasi siklus II menunjukan peningkatan pemahaman siswa terhadap konsep yang telah dipelajari sudah mulai dengan baik. Hal ini dapat dilihat dari kemampuan siswa mengembangkan dan menginterprestasikan materi sudah menggunakan penalaran dan berpikir kritis, sehingga proses belajar mengajar dapat berjalan dengan 
baik dan lancar serta target yang diinginkan dapat tercapai, antusias siswa yang tinggi, sehingga suasana kelas jadi semarak.

Berdasarkan pengamatan dan analisis terhadap aktivitas pembelajaran serta situasi kondisi lingkungan belajar, maka pada siklus II di dapatkan bahwa : (1) Konsentrasi dan semangat siswa lebih meningkat dari pada siklus I (2) Guru lebih memahami dan siap dalam mengajar dan tetap mempertahankan penampilan seperti sebelumnya (3) Siswa sudah bisa mengembangkan materi yang telah dipelajari sehingga hal ini dapat meningkatkan prestasi belajar siswa menjadi lebih baik (4) Dengan adanya media gambar seri maka dapat menumbuh kembangkan semangat siswa belajar.

Dari analisis data yang diuraikan diatas, maka disimpulkan bahwa aktivitas guru dan siswa serta hasil belajar pada siklus II sudah meningkat, karena itu diputuskan untuk tidak melanjutkan penelitian pada siklus berikutnya. Dengan demikian penelitian ini selesai.

\section{PEMBAHASAN}

Pembahasan hasil penelitian terdiri atas tiga tahap, yaitu (1) kegiatan awal, (2) kegiatan inti, (3) kegiatan akhir. Sebelum diuraikan tahap tersebut akan diuraikan terlebih dahulu perencanaan tindakan. Berdasarkan hasil penelitian penggunaan media gambar seri meningkatkan keterampilan berbicara siswa bahwa rencana pembelajaran yang dibuat secara kolaboratif dengan guru kelas III SDN. 14 Siguntur Muda Kecamatan Koto XI Tarusan Kabupaten Pesisir Selatan. Dalam perencanaan terdapat unsur-unsur, Standar Kompetensi (SK), Kompetensi Dasar (KD), indikator, langkah-langkah pembelajaran, media, dan penilaian.

\section{Pembahasan Hasil Penelitian Siklus I}

Pada kegiatan awal, yaitu: mengkondisikan kelas, menyampaikan tujuan pembelajaran, bertanya jawab tentang materi yang akan dipelajari, memotivasi siswa untuk memperhatikan media gambar seri yang dipajang.

Dari hasil penelitian diketahui bahwa pada siklus I kegiatan ini kurang berjalan dengan baik, guru kurang memotivasi siswa untuk aktif serta dalam bertanya jawab dengan siswa guru kurang dalam penguasaan materi tanya jawab dan guru kurang dalam memotivasi siswa untuk belajar sehingga proses pembelajaran terlihat kurang efektif. Pada tahap kegiatan inti masih kurang optimal. Hal ini disebabkan karena guru kurang membimbing siswa untuk mau berbicara di depan kelas karena siswa masih ada yang malu-malu untuk memperagakan percakapanya.

Pada kegiatan akhir, yaitu: dalam menyimpulkan pelajaran siswa masih banyak tidak ingat pelajaran yang telah dipelajari sehingga guru yang lebih banyak berbicara. Hal ini disebabkan karena guru kurang membimbing siswa dan memotivasi siswa, sehingga siswa kurang mengerti dan kurang aktif dalam pembelajaran.

\section{Pembahasan Hasil Penelitian Siklus II}

Pada siklus II kegiatan awal, yaitu: mengkondisikan kelas, menyampaikan tujuan pembelajaran, bertanya jawab tentang materi yang akan dipelajari, memotivasi siswa untuk memperhatikan media gambar seri yang dipajang sudah terlaksana dengan baik dan sehingga hasil pembelajarannya sudah menunjukkan peningkatan.

Pada tahap kegiatan inti sudah terlaksana dengan baik. Guru telah memberikan contoh kepada siswa bagaimana cara memperagakan percakapan secara baik didepan kelas, sehingga siswa dengan antusias untuk memperagakan percakapan yang mereka buat.

Pada tahap kegiatan akhir merupakan tahap menyimpulkan pembelajaran. Kegiatan ini sudah terlaksana dengan baik, guru memberikan arahan kepada siswa bagaimana menyimpulkan pembelajaran secara baik.

Tabel 8. Rekapitulasi nilai ketuntasan kemampuan berbicara melalui media gambar seri

Ketuntasan hasil belajar siswa secara klasikal Siklus I

$35,71 \%$
Ketuntasan hasil belajar siswa secara klasikal

Siklus II

$\mathbf{9 2 , 8 5 \%}$ 
Dapat terlihat pada tabel di atas, hasil tes pada setiap siklus menunjukkan peningkatan. Hal ini terlihat pada persentase ketuntasan belajar secara klasikal. Pada siklus I terdapat 35,71\% siswa yang tuntas belajar dengan ratarata skor tes 50 . Sedangkan pada siklus II terdapat $92,85 \%$ siswa yang tuntas belajar dengan rata-rata skor tes 83,93. Dengan demikian, persentase ketuntasan secara klasikal dan rata-rata hasil belajar siswa mengalami peningkatan yang signifikan.

\section{SIMPULAN DAN SARAN}

Dari pembahasan yang dijelaskan, maka dapat disimpulkan bahwa melalui media gambar seri dapat ditingkatkan proses pembelajaran kemampuan berbicara siswa kelas III SDN. 14 Siguntur Muda Kecamatan Koto XI Tarusan Kabupaten Pesisir Selatan.

Melalui media gambar seri dapat meningkatkan kemampuan berbicara siswa berdasarkan hasil penelitian dimana terdapat peningkatan pada setiap siklusnya, pada siklus I rata-rata persentasenya 50\%, sedangkan pada siklus II rata-rata persentasenya $83,92 \%$. Hal ini menujukkan pada setiap siklusnya terjadi peningkatan kemampuan berbicara siswa menggunakan media gambar seri.

Berdasarkan pengalaman selama melaksanakan penelitian tindakan kelas di kelas III SDN. 14 Siguntur Muda, ada beberapa saran penulis kepada siswa, guru, dan sekolah. Bagi Siswa, sebaiknya siswa mendengarkan penjelasan guru dengan serius saat guru memberikan pengarahan tentang pembelajaran dengan media gambar seri. Bagi guru, sebaiknya guru lebih kreatif dalam menyajikan pembelajaran dengan media gambar seri agar tidak menimbulkan kebosanan bagi siswa. Bagi sekolah, kepala sekolah sebaiknya menyarankan kepada guru-guru untuk menguasai berbagai model pembelajaran, khususnya pembelajaran dengan menggunakan media gambar seri.

\section{DAFTAR RUJUKAN}

Amra, Abhanda. (2010). Media Pembelajaran Untuk Sekolah dan Madrasah. BatuSangkar: STAIN Batu Sangkar Press.

Arikunto, Suharsimi. (2006). Penelitian Tindakan Kelas. Jakarta: Bumi Akasara.

Depdiknas. (2006). Kurikulum Tingkat Satuan Pendidikan Jenjang Pendidikan Dasar. Jakarta: Departemen Pendidikan Nasional.

Fitri, E., Ifdil, I., \& Neviyarni, S. (2016). Efektivitas layanan informasi dengan menggunakan metode blended learning untuk meningkatkan motivasi belajar. Jurnal Psikologi Pendidikan dan Konseling: Jurnal Kajian Psikologi Pendidikan dan Bimbingan Konseling, 2(2), 84-92.

Hairuddin. (2007). Pembelajaran Bahasa Indonesia.Jakarta: Direktorat Jenderal Pendidikan Tinggi.Departemen Pendidikan Nasional.

Lana, Agusli. dkk. (1984). Keterampilan Berbicara. Padang: Badan Penerbit Jurusan Pendidikan Bahasa Indonesia Pada Bahasa Dasar Institut Keguruan dan Ilmu Pendidikan (IKIP)

Mulyasa. (2010). Kurikulum Tingkat Satuan pendidikan. Bandung: Remaja Rosda karya.

Mustika, Agriani. (2012). Peningkatan Keterampilan Berbicara Melalui Media Gambar Seri, Padang: Universitas Bung Hatta.

Santoso, Puji. (2005). Materi Dan Pembelajaran Bahasa Indonesia SD. Jakarta: Universitas Terbuka.

Sudjana, Nana. (2009). Media Pembelajaran. Bandung: Sinar Baru Algensido.

Sugiyono, (2007). Metode penelitian Pendidikan. Jakarta: Alfabeta.

Sumantri, Mulyani. (2005). Perkembangan Peserta Didik, Jakarta: Universitas Terbuka

Syofiani. (2007). Bahan Ajar dan Retorika. Padang: FKIP UBH.

Tarigan, Hendry Guntur. (2007). Teknik Pengajaran Keterampilan Berbahasa. Bandung: Angkasa.

Usman, Basyiruddin. (2002). Media Pembelajaran. Jakarta: Ciputat pers

Waardhani, IGAK. (2008). Penelitian Tindakan Kelas. Jakarta: Universitas Terbuka.

Wahyuni, Sri. (2011). Meningkatkan Kemampuan Menulis Karangan Narasi Melalui Gambar Seri, Padang: Universitas Bung Hatta 